\title{
Early intervention is the key to success in COVID-19 control
}

\author{
Rachelle N. Binny ${ }^{1,4}$, Michael G. Baker ${ }^{5,6}$, Shaun C. Hendy ${ }^{3,4}$, Alex James ${ }^{2,4}$, Audrey \\ Lustig $^{1,4}$, Michael J. Plank ${ }^{2,4}$, Kannan M. Ridings ${ }^{3,4}$, Nicholas Steyn $n^{2,3,4}$
}

1. Manaaki Whenua, Lincoln, New Zealand.

2. School of Mathematics and Statistics, University of Canterbury, New Zealand.

3. Department of Physics, University of Auckland, New Zealand.

4. Te Pūnaha Matatini: the Centre for Complex Systems and Networks, New Zealand.

5. Department of Public Health, University of Otago, Wellington, New Zealand

6. Maurice Wilkins Centre for Molecular Biodiscovery, New Zealand.

\begin{abstract}
New Zealand responded to the COVID-19 pandemic with a combination of border restrictions and an Alert Level system that included strict stay-at-home orders. These interventions were successful in containing the outbreak and ultimately eliminating community transmission of COVID-19. The timing of interventions is crucial to their success. Delaying interventions may both reduce their effectiveness and mean that they need to be maintained for a longer period. Here, we use a stochastic branching process model of COVID-19 transmission and control to simulate the epidemic trajectory in New Zealand and the effect of its interventions during its COVID-19 outbreak in March-April 2020. We use the model to calculate key measures, including the peak load on the contact tracing system, the total number of reported COVID-19 cases and deaths, and the probability of elimination within a specified time frame. We investigate the sensitivity of these measures to variations in the timing of interventions and show that changing the timing of Alert Level 4 (the strictest level of restrictions) has a far

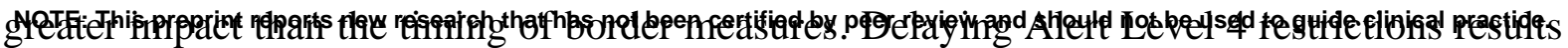


medRxiv preprint doi: https://doi.org/10.1101/2020.10.20.20216457; this version posted March 22, 2021. The copyright holder for this preprint (which was not certified by peer review) is the author/funder, who has granted medRxiv a license to display the preprint in It is made available under a CC-BY-NC-ND 4.0 International license .

25 in considerably worse outcomes and implementing border measures alone, without Alert Level 4 restrictions, is insufficient to control the outbreak. We conclude that the rapid response in introducing stay-at-home orders was crucial in reducing the number of cases and deaths and increasing the probability of elimination.

Keywords: infectious disease outbreak; non-pharmaceutical interventions; stochastic model;

COVID-19; coronavirus; border restrictions 
medRxiv preprint doi: https://doi.org/10.1101/2020.10.20.20216457; this version posted March 22, 2021. The copyright holder for this

preprint (which was not certified by peer review) is the author/funder, who has granted medRxiv a license to display the preprint in It is made available under a CC-BY-NC-ND 4.0 International license .

\section{Introduction}

An outbreak of COVID-19, a novel zoonotic disease caused by the SARS-CoV-2 virus, was first detected in Wuhan, China in November 2019. The virus spread rapidly to other countries resulting in a pandemic being declared by the World Health Organisation in March 2020.

Governmental policy responses to COVID-19 outbreaks have varied widely among countries, in terms of the nature and stringency of policy interventions, how quickly these interventions were implemented (Table S2) (Desvars-Larrive et al., 2020) and their effectiveness at reducing spread of the virus (Flaxman et al., 2020; Hsiang et al., 2020; Binny et al., 2020a). While it is tempting to judge the success of interventions by comparison across jurisdictions, this assessment may be confounded by local context that may influence success, as well as by the fact that policy choices can be driven by the severity of initial outbreaks. Models of disease spread played an important role in the design and timing of interventions, but they can also be used post hoc, to evaluate the effectiveness of those interventions. For example, Flaxman et al. (2020) and Brauner et al. (2020) fitted models of disease dynamics to case count and death data in different countries to estimate the effect of specific nonpharmaceutical interventions on the transmission rate of COVID-19. Modelling studies have indicated the importance of timely interventions for achieving local elimination and averting resurgent waves of COVID-19 in locations like New Zealand and the Australian state of Victoria (Parag et al., 2021).

In response to the escalating COVID-19 pandemic and the outbreak that was establishing in New Zealand in March 2020, a number of policy interventions were implemented to mitigate risk at the border and reduce community transmission. From 15 March 2020 (11.59pm), all international arrivals were required to 'self-isolate' (home quarantine) for 14 days. On 19 
medRxiv preprint doi: https://doi.org/10.1101/2020.10.20.20216457; this version posted March 22, 2021. The copyright holder for this preprint (which was not certified by peer review) is the author/funder, who has granted medRxiv a license to display the preprint in It is made available under a CC-BY-NC-ND 4.0 International license .

March 2020, the border was closed to everyone except returning citizens and residents. A system of four alert levels was introduced on 21 March with the Alert Level initially set at Level 2. On 23 March, it was announced that the Alert Level was increasing to Level 3, and that the country would move to Alert Level 4 as of $11.59 \mathrm{pm}$ on 25 March, signalling that New Zealand was taking a decisive COVID-19 response that would eventually become an elimination strategy (Baker et al., 2020b). At the time Alert Level 4 came into effect, there had been 315 reported (confirmed and probable) cases. Alert Level 4 stayed in place until 27 April when restrictions were eased to Alert Level 3. On 13 May, after 16 days at Alert Level 3, daily new cases had dropped to three and there was a phased easing into Alert Level 2 (Table 1). The seven weeks spent under stringent Alert Level 3 or 4 restrictions, which included stay-at-home orders (see Appendix Table S4 for full list of measures) alongside systems for widespread testing, contact tracing and case isolation, were effective at reducing transmission (effective reproduction number, $R_{\text {eff }}=1.8[95 \%$ CI $1.44,1.94]$ prior to Alert Level $4 ; R_{\text {eff }}=0.35[0.28$, 0.44] during Alert Level 4; Binny et al., 2020b, James et al., 2020c). Daily numbers of new cases declined to zero or one by mid May and the last case of COVID-19 associated with the March outbreak was reported on 22 May. A descriptive epidemiological study by Jefferies et al. (2020) provides a comprehensive account of SARS-CoV-2 transmission patterns, testing patterns, demographic features and disease outcomes in New Zealand during this period. On 8 June, after 17 consecutive days with no new reported cases, New Zealand officially declared elimination of community transmission following WHO guidelines (Baker et al., 2020c). This decision is supported by modelling work estimating the probability of elimination at this time (Binny et al., 2020c; Parag et al., 2021; Wilson et al., 2020). Between 22 May and 11 August, the only new cases detected were in international arrivals who were required to spend 14 days in government-managed isolation or quarantine facilities (Baker et al., 2020c). On 9 August 2020, New Zealand reached a milestone of 100 days with no community transmission. 
medRxiv preprint doi: https://doi.org/10.1101/2020.10.20.20216457; this version posted March 22, 2021. The copyright holder for this preprint (which was not certified by peer review) is the author/funder, who has granted medRxiv a license to display the preprint in It is made available under a CC-BY-NC-ND 4.0 International license .

105

106

Table 1: Dates of implementation for policy interventions during New Zealand's COVID-19 response. All interventions were implemented at 11.59pm.

\begin{tabular}{l|l}
\hline $\begin{array}{l}\text { Date } \\
\text { implemented }\end{array}$ & Policy Intervention \\
\hline 15 March & 14-day self-isolation (i.e. home quarantine) for all international arrivals \\
19 March & Border closed except to returning residents and citizens \\
21 March & Alert Level 2 \\
23 March & Alert Level 3 \\
25 March & Alert Level 4 \\
9 April & Mandatory 14-day government-managed quarantine for all international \\
& arrivals \\
27 April & Alert Level 3 \\
13 May & Alert Level 2 (schools and bars remain closed, gathering size limit 10) \\
18 May & Schools reopen \\
21 May & Bars reopen \\
25 May & Gathering size limit increased to 100 \\
8 June & Alert Level 1: all restrictions lifted except border measures \\
\hline
\end{tabular}

A comparison of the outcomes of New Zealand's COVID-19 response with predicted outcomes from hypothetical alternative actions is important for evaluating the effectiveness of the interventions made and to help refine future response strategies. In this work, we first model the factual scenario using New Zealand's actual intervention timings, then compare this to counterfactual (alternative 'what if') scenarios where policy interventions were implemented earlier or later than occurred in reality, to assess what impact this could have had for COVID19 spread in New Zealand. For each scenario, we simulate a model of COVID-19 spread and compare key measures, including the peak load on the contact tracing system, the cumulative numbers of cases and deaths, and the probability of elimination predicted by the model. Here, we define elimination as there being no active cases (we assume a case remains 'active' for 30 days after date of exposure) that could contribute to future community transmission. This definition excludes cases in international arrivals after 9 April 2020 who were required to spend 14 days in government-managed isolation and quarantine facilities. Similar definitions employing 28 days after date of exposure (which is twice the maximum incubation period) 
medRxiv preprint doi: https://doi.org/10.1101/2020.10.20.20216457; this version posted March 22, 2021. The copyright holder for this preprint (which was not certified by peer review) is the author/funder, who has granted medRxiv a license to display the preprint in It is made available under a CC-BY-NC-ND 4.0 International license .

have been proposed (Baker et al., 2020a). The date of exposure for an infected individual is often unknown and is instead inferred from date of symptom onset; our 30-day definition provides some buffer for potential error arising during this estimation.

In particular, we assess how important New Zealand's decision to move 'hard and early' was for the successful elimination of community transmission following the March-April outbreak. To this end, we compare scenarios with different timings until the start of Alert Level 4 to see how these choices could have affected the size of the outbreak. While Alert Level 4 was successful in achieving elimination, the benefits of elimination had to be weighed against the negative impacts of stringent stay-at-home measures, for example job losses, financial insecurity, and disruption to education and economic activity. If careful border management could have avoided the need for a lockdown or reduced its intensity, this approach may have been preferable. For instance, Taiwan's early border closure, travel restrictions and 14-day quarantine for those entering the country have meant that, to date, Taiwan has avoided a mass lockdown (Summers et al., 2020). We explore whether introducing border restrictions (requiring 14-day self-isolation for all international arrivals) earlier in New Zealand might have been sufficient to eliminate or reduce transmission from international arrivals to the extent where stringent Alert Level 4 restrictions could have been avoided or less restrictive measures been sufficient. Compared to other countries, New Zealand was very quick to close its border to all except returning citizens and residents (Table S2). We explore a scenario where border closure is delayed by 5 days to assess how much larger the outbreak might have been had New Zealand been slower to act. We also consider a scenario where timings of two interventions are altered, to check whether this combination amplifies or counteracts the outcome trends found in scenarios where timings are varied for interventions individually. However we do not perform exhaustive comparisons of all possible combinations of different timings for all 
medRxiv preprint doi: https://doi.org/10.1101/2020.10.20.20216457; this version posted March 22, 2021. The copyright holder for this

preprint (which was not certified by peer review) is the author/funder, who has granted medRxiv a license to display the preprint in It is made available under a CC-BY-NC-ND 4.0 International license .

148

interventions. Finally, we consider a scenario with no Alert Level 4/3 restrictions to compare the size of outbreak that New Zealand could have experienced if border restrictions and closure had been the only control measures.

In this study, we focus on the timing of interventions; we do not explicitly consider the duration of interventions, although this will be investigated in future work. Indeed, the likelihood of elimination was one of the factors taken into account in New Zealand government decisionmaking concerning the duration of Alert Levels (DPMC, 2020).

\section{Methods}

We simulated a stochastic model of COVID-19 spread in New Zealand (James et al., 2020a; Hendy et al., 2021) under a factual scenario using actual timings for border restrictions, border closure and Alert Level 4, and for counterfactual scenarios in which implementation of these interventions were either delayed or started earlier. Case data were obtained from Ministry of Health, containing arrival dates, symptom onset dates, isolation dates and reporting dates for all international cases arriving in New Zealand between February and June 2020. The model is a continuous time branching process that is seeded with internationally imported cases and simulates the numbers of new clinical and subclinical cases that are acquired through local transmission each day (see Appendix for full model specification and Table S1 for list of model parameters). It accounts for delays from infection to symptom onset, and from symptom onset to date of reporting. We assume that the time between an individual becoming infected and infecting another individual (the generation time) follows a Weibull distribution, with a mean and median of 5 days and standard deviation of 1.9 days (Ferretti et al., 2020). The model incorporates individual heterogeneity in transmission rate 
medRxiv preprint doi: https://doi.org/10.1101/2020.10.20.20216457; this version posted March 22, 2021. The copyright holder for this

preprint (which was not certified by peer review) is the author/funder, who has granted medRxiv a license to display the preprint in It is made available under a CC-BY-NC-ND 4.0 International license .

(e.g. super-spreaders) and assumes that a proportion of clinical cases are undetected by testing and do not get reported, as described in James et al. (2020a). It assumes that subclinical cases are not reported and do not self-isolate. Except for heterogeneity in an individual's reproduction number, individuals are otherwise assumed to be homogenous and the population well mixed. Each clinical case is assumed to have a fixed probability of resulting in fatality, calculated using an infection fatality rate (IFR) of $0.88 \%$; this value was obtained by fitting age-specific COVID-19 IFR estimates from international studies (Verity et al, 2020) to the age distribution of the New Zealand population from 2018 Census data (Statistics New Zealand, 2020).

We account for three classes of interventions for reducing onward transmission: (i) selfisolation (i.e. home quarantine), simulated as a reduction in an individual's transmission rate relative to their transmission when not isolated; (ii) government-managed isolation and quarantine (MIQ), which we assume is $100 \%$ effective at preventing onward transmission; (iii) population-wide control, modelled as a reduction in transmission rate by a factor $C(t)$ at time $t$, relative to no population-wide control, due to restrictions under each of the four Alert Levels. The relative transmission rate is $C(t)=1$ in the absence of population-wide control and higher Alert Levels correspond to smaller values of $C(t)$ and an associated reduction in effective reproduction number $R_{\text {eff }}$. Reproduction number has a large impact on the probability of extinction in a branching process and is related, via the generation time distribution, to the rate of exponential growth during the early phase of an outbreak (Wallinga \& Lipsitch, 2007). Rather than reducing reproduction number in the branching process, the effect of border closure is to reduce the number of seed cases, i.e. the number of new independent branches. 
medRxiv preprint doi: https://doi.org/10.1101/2020.10.20.20216457; this version posted March 22, 2021. The copyright holder for this preprint (which was not certified by peer review) is the author/funder, who has granted medRxiv a license to display the preprint in It is made available under a CC-BY-NC-ND 4.0 International license .

In each scenario, we kept the duration of each Alert Level (AL) the same as actually occurred, i.e. 33 days at AL4 followed by 16 days at AL3. We explored the following scenarios (see Table 1):

\section{Border restrictions, border closure and AL4 implemented on actual dates.}

1. Early AL4. Border restrictions and closure implemented on actual dates, and start of AL4 implemented 5 days early.

2. Delayed AL4. Border restrictions and closure implemented on actual dates, and start of AL4:
a. delayed by 5 days,
b. delayed by 10 days,
c. delayed by 20 days.

3. Early border restrictions. Border restrictions 5 days earlier; border closure and AL4 on actual dates.

4. Delayed border closure. Border closure delayed by 5 days; border restrictions and AL4 on actual dates.

\section{Change in timing of AL4, border restrictions and closure:}

a. Border restrictions 5 days early and AL4 5 days early; border closure on actual date.

b. Border closure and AL4 delayed by 5 days; border restrictions on actual date.

6. No AL4. No AL3 or AL4 implemented; border restrictions and closure on actual dates.

Border restrictions, border closure and start of AL4 were all implemented at $11.59 \mathrm{pm}$ so we start simulating their effects on the day after their implementation date. For scenarios $0,1,2,3$ and 6, the model was seeded with the same number of international cases as were reported in case data, using their actual dates of arrival, symptom onset and reporting. For each of these case cases, the date of exposure was estimated backwards from the date of symptom onset. In 
medRxiv preprint doi: https://doi.org/10.1101/2020.10.20.20216457; this version posted March 22, 2021. The copyright holder for this preprint (which was not certified by peer review) is the author/funder, who has granted medRxiv a license to display the preprint in It is made available under a CC-BY-NC-ND 4.0 International license .

scenarios where border restrictions were implemented on the actual start date (15 March; Scenarios $0,1,2,4$ and 6), the self-isolation dates of international cases were set to the same isolation dates as were actually reported. In all scenarios, prior to 9 April the modelled effect of self-isolation is to reduce an individual's transmission rate to $65 \%$ of their transmission when not isolated (following the assumed value used in a model of COVID-19 transmission dynamics by Davies et al., 2020). This reflects some risk of onward transmission for cases selfisolating at home. After 9 April, the model assumes that all international cases are placed in MIQ facilities and do not contribute to local transmission. We also simulated a Poissondistributed random number of international subclinical cases in proportion to the number of international clinical cases (assuming $1 / 3$ of all cases are subclinical), with arrival and symptom onset dates that were randomly sampled with replacement from the international case data. We assume that these international subclinical cases are not detected and therefore do not selfisolate, but those arriving after 9 April are placed in MIQ and therefore do not contribute to community transmission.

To simulate border restrictions starting 5 days early (Scenarios 3 and 5a), international cases arriving between the earlier start date and the actual start date (11 - 15 March, inclusive) were assumed to be self-isolated on their date of arrival. To simulate a 5-day delay to border closure (Scenarios 4 and 5b), we delayed the arrival dates (and associated symptom onset, reporting and isolation dates) of international seed cases arriving after 19 March by 5 days. We then allowed for new international cases arriving over these 5 days (e.g. additional non-residents that may have chosen to travel had the border remained open for longer) by seeding an additional Poisson-distributed random number of international cases from 20 March to 24 March, with an average daily number of seeded cases equal to the actual average daily number of international cases arriving during the week prior to 19 March (33 international cases per 
medRxiv preprint doi: https://doi.org/10.1101/2020.10.20.20216457; this version posted March 22, 2021. The copyright holder for this

preprint (which was not certified by peer review) is the author/funder, who has granted medRxiv a license to display the preprint in It is made available under a CC-BY-NC-ND 4.0 International license .

day). These additional seeded cases were assumed to self-isolate on arrival and their delays from arrival-to-symptom onset and arrival-to-reporting were randomly sampled with replacement from the corresponding delays in the actual international case data (obtained from Ministry of Health). We did not attempt to simulate scenarios with delayed border restrictions or earlier border closure because these would have required additional, more substantial modelling assumptions about isolation dates of international arrivals and about the reduction in the volume of international arrivals resulting from border closure. Model predictions would have been highly sensitive to these major assumptions and, without data available to validate them, this would introduce considerable model uncertainty.

For each scenario, we assessed the following key measures describing the dynamics of a COVID-19 outbreak:

1. The maximum contact tracing (or health system) load, by calculating the maximum number of daily new reported cases and the date on which this occurred.

2. The number of daily new reported cases at the end of AL4.

3. Cumulative number of reported cases and the cumulative number of deaths at the end of the seven week period of Alert Level 3-4 restrictions (i.e. end of AL3).

4. Probability of elimination, $P($ elim $), 5$ weeks after the end of AL3.

The first measure is useful for assessing whether the contact tracing or health system capacity would have been exceeded. The second measure indicates the daily incidence of cases after four weeks of the most stringent restrictions under AL4, and at the time when restrictions are eased to AL3 (meaning schools, years 1 to 10, and Early Childhood Education centres can reopen with limited capacity, and non-essential businesses can re-open premises but cannot physically interact with customers; see Appendix Table S4). The third measure quantifies the overall health cost of the outbreak. Given New Zealand's elimination strategy (Baker et al., 
medRxiv preprint doi: https://doi.org/10.1101/2020.10.20.20216457; this version posted March 22, 2021. The copyright holder for this

preprint (which was not certified by peer review) is the author/funder, who has granted medRxiv a license to display the preprint in It is made available under a CC-BY-NC-ND 4.0 International license .

2020b), we included the fourth measure to assess the likelihood of achieving elimination of community transmission under the different intervention timings. This is an important consideration because in scenarios resulting in low probabilities of elimination after AL3 restrictions are eased, there is a higher risk of cases persisting undetected in the community and sparking a new outbreak under the weaker AL2 restrictions. For example, gatherings of up to 100 people are permitted under AL2, increasing the risk of super-spreading events. If a new outbreak did occur then another lockdown may be required and the overall health cost would be even higher than that of our third key measure.

In Scenarios 1-5, the model was simulated from 1 February 2020 until a date 5 weeks after the end of AL3 (end dates therefore vary between scenarios depending on Alert Level timings). In Scenario 6, simulations were run up to 1 February 2021 to allow sufficient time for the outbreak to run its full course. We performed 5000 realisations of the model and report the average value of each key measure as well as the interval range within which $90 \%$ of simulation results were contained (in square brackets throughout). In the model, P(elim) was calculated as the proportion of all model realisations that resulted in elimination, defined as no remaining cases within 30 days of infection on the date 5 weeks after the end of AL3 (or in Scenario 6 with no AL4/3 restrictions, no remaining cases within 30 days of infection on 18 June 2020, i.e. 5 weeks after the end of actual AL3).

Simulations were run using previously published estimates of the reproduction number $R_{\text {eff }}$ that provided the best fit to actual data before and during AL4 (Binny et al., 2020b). For the period prior to AL4, $R_{\text {eff }}=1.8$ which reflects the average level of transmission in the period prior to 21 March (when there was a heightened public awareness of the risk of community transmission, as the first domestic cases were detected in New Zealand) and during the 2-day 
medRxiv preprint doi: https://doi.org/10.1101/2020.10.20.20216457; this version posted March 22, 2021. The copyright holder for this preprint (which was not certified by peer review) is the author/funder, who has granted medRxiv a license to display the preprint in It is made available under a CC-BY-NC-ND 4.0 International license .

periods in AL2 and AL3. During AL4, $R_{\text {eff }}=0.35$. Under the Alert Levels 3, 2 and 1, which followed the lockdown, the daily numbers of new cases were too low to obtain reliable estimates of the effective reproduction number $R_{\text {eff }}$ from these data using standard techniques (e.g. see Obadia et al. (2012) for a review of methods). Instead we simulated the model for assumed values of $R_{\text {eff }}=0.95,1.7$ and 2.4, respectively. The estimate of $R_{\text {eff }}=2.4$ at AL1 (minimal restrictions, schools and businesses fully open and no limits on gathering size) is in line with estimates reported in Plank et al (2020), for the pre-lockdown period of New Zealand's August-September outbreak, when community transmission was considered to be eliminated and the country was at AL1. Plank et al (2020) obtained these estimates using two independent methods: (i) performing Monte Carlo reconstructions of epidemiological transmission trees using contract tracing data (James et al., 2020c), and (ii) fitting the Hendy et al. (2021) stochastic branching process model to daily reported case count data. The value of $R_{\text {eff }}$ at AL2 would likely be lower than at AL1 but greater than one due to relatively high activity levels and contact rates as stay-at-home orders are lifted and public venues, businesses and schools re-open. The estimate of $R_{\text {eff }}=1.7$ at AL2 is in the range of estimated values for the pre-lockdown period of the March-April outbreak given in Plank et al (2020). The $R_{\text {eff }}$ for AL3 was chosen to be less than 1, however we tested the sensitivity of our results to using a value greater than one. For the scenario with no stringent Alert Level restrictions (Scenario 6), we simulated the model using $R_{\text {eff }}=1.8$ for the entire period (i.e. the same value as was used in all Scenarios for the period prior to AL4). This value is lower than that of AL1, reflecting a likelihood of substantial behaviour change and heightened public awareness of the risks of community transmission, even in the absence of any alert level restrictions.

\section{Sensitivity analyses}


medRxiv preprint doi: https://doi.org/10.1101/2020.10.20.20216457; this version posted March 22, 2021. The copyright holder for this preprint (which was not certified by peer review) is the author/funder, who has granted medRxiv a license to display the preprint in It is made available under a CC-BY-NC-ND 4.0 International license .

We further investigated how varying the length of the delay (in days) until the start of AL4 (cf. the delays chosen in Scenario 2) affected key measures. Similarly, we assessed the effect on the key measures of introducing border restrictions 10 days early (cf. 5 days early in Scenario 3). We also tested the sensitivity of our results to different choices of relative transmission rate $C(t)$ (corresponding to changes in $R_{\text {efff }}$ ) under AL3, in particular for a less effective AL3 $\left(C(t)=0.46 ; R_{e f f}=1.1\right)$ and a more effective AL3 $\left(C(t)=0.30 ; R_{e f f}=0.7\right)$. Previous studies have considered the sensitivity of the branching process model predictions to variations in model parameters whose values are uncertain or context-specific (James et al., 2020a; Binny et al, 2020b; Binny et al, 2020c). Multiple dependencies exist between certain model parameters and the overall population reproduction number $R_{\text {eff, }}$ as described in James et al (2020a). There is further dependency between $R_{\text {eff }}$ and the probability of elimination $P\left(\right.$ elim) such that a reduction in $R_{\text {eff }}$ corresponds to an increase in $P($ elim). James et al (2020a) compared model outputs for different values of the proportion and relative infectiousness of subclinical infections, the individual heterogeneity in transmission rate, and the mean generation time. Changes in these parameters that resulted in a change in the overall population reproduction number, $R_{e f f}$, caused a corresponding change in the outbreak trajectory. However, if $R_{\text {eff }}$ was set to a fixed value the model was robust to changes in these parameters. Increasing the individual heterogeneity in transmission rate increases the variation between independent realisations of the model and increases $P($ elim) (Lloyd-Smith et al, 2005). The best-fit $R_{\text {eff }}$ estimates for AL4 were also relatively insensitive to changes in model parameters (Binny et al., 2020b).

\section{Results}

Scenario 0 
medRxiv preprint doi: https://doi.org/10.1101/2020.10.20.20216457; this version posted March 22, 2021. The copyright holder for this preprint (which was not certified by peer review) is the author/funder, who has granted medRxiv a license to display the preprint in It is made available under a CC-BY-NC-ND 4.0 International license .

To check that the model could accurately replicate the outbreak, we first simulated our model under a factual scenario with border restrictions, border closure and AL4 implemented on the dates they actually occurred. The predicted dynamics of daily new reported cases were a very good visual match to observed daily case data (Fig. 1) and predicted key measures showed good agreement with the values that were actually observed (Table 2, bold text). After moving into AL4, the model prediction and the actual number of daily new reported cases both levelled off at 70-80 for around one week before case numbers started to decline (Fig. 1). In actual case data, the maximum of 84 new cases per day was observed at the start of this flat-topped peak, while our model predicted a similar maximum $(80[67,99]$ new cases per day) occurring 6 days later. By the end of AL3, the model predicted similar cumulative totals to the 1503 cases and 22 deaths actually reported. Five weeks after AL3 restrictions were relaxed, elimination of community transmission of COVID-19 was achieved in $66 \%$ of model simulations, giving $P($ elim $)=0.66$ (Table 2). As we discuss later, higher estimates of probability of elimination reported when New Zealand declared elimination on 9 June were obtained by making use of additional information from case data on the number of consecutive days with zero new reported cases (Binny et al., 2020c). In the following counterfactual scenarios with alternative timings of interventions, we use Scenario 0 as a baseline for comparing key measures.

\section{Scenario 1: Early AL4}

Under a scenario where AL4 was implemented 5 days earlier (one day after border closure), the model predicts slightly lower values for most key measures than were actually observed: daily new cases peaked at a lower level of $69[61,79]$ cases around 26 March and at the end of AL4 had dropped to a similar level of 4 new cases per day as was actually observed (Fig. 1). By the end of the 7 weeks of AL4/3 it predicts approximately 500 fewer cases in total and 10 fewer deaths (Table 2; Scenario $1 \mathrm{cf}$. Scenario 0). However, this estimate should be taken with 
medRxiv preprint doi: https://doi.org/10.1101/2020.10.20.20216457; this version posted March 22, 2021. The copyright holder for this preprint (which was not certified by peer review) is the author/funder, who has granted medRxiv a license to display the preprint in It is made available under a CC-BY-NC-ND 4.0 International license .

caution because of the small numbers of daily cases and fine-scale variations involved: for instance, whether an outbreak occurred in an aged care facility or not. Five weeks after AL3, the probability of elimination was $63 \%$, slightly lower than in Scenario 0 . This counter-intuitive result is due to the presence of an international case in the data that had an arrival date prior to the start of AL4 (25 March) but a much later symptom onset date near the end of AL4. In Scenario 0, when international cases are seeded in the model using the actual dates of arrival, sympton onset, reporting and isolation from the case data (see Appendix for details), this individual's peak transmission rate occurs during AL4. However, in Scenario 1, the earlier start to AL4 means that the individual is instead most infectious during AL3, where $R_{\text {eff }}$ is higher, so this individual infects more people, on average, in this scenario than in Scenario 0. Similarly, any simulated subclinical infections with the same arrival and symptom onset dates (which are sampled with replacement from the international case data) will also be most infectious during AL3. These subclinical infections do not appear in the numbers of reported cases but will reduce the probability of elimination. If this international case outlier is excluded from the data, the model predicts a very similar probability of elimination in both scenarios. 
Table 2: Key measures from alternative scenarios of early or delayed implementation of policy interventions: the maximum number of daily new reported cases, date on which the peak occurs, the number of daily new cases at the end of the simulated Alert Level 4 period, the cumulative number of cases and the total number of deaths at the end of the simulated 7 week period of Alert Level 4/3 restrictions (dates given in 'AL3 ends' and footnotes). For each measure, except P(elim), the mean value from 5000 simulations is reported alongside the interval range, in parentheses, in which $90 \%$ of simulations results are contained.

\begin{tabular}{|c|c|c|c|c|c|c|c|c|c|c|}
\hline $\begin{array}{l}\text { Scenari } \\
\text { o }\end{array}$ & $\begin{array}{l}\text { Border } \\
\text { self- } \\
\text { isolatio } \\
n\end{array}$ & $\begin{array}{l}\text { Border } \\
\text { closed }\end{array}$ & $\begin{array}{c}\text { AL4 } \\
\text { starts }\end{array}$ & $\begin{array}{l}\text { AL3 } \\
\text { ends }\end{array}$ & $\begin{array}{l}\text { Max. new } \\
\text { daily cases }\end{array}$ & Date of peak & $\begin{array}{c}\text { New daily } \\
\text { cases at } \\
\text { end of } \\
\text { AL4 }\end{array}$ & $\begin{array}{c}\text { Cumulative } \\
\text { reported cases }\end{array}$ & Total deaths & $\begin{array}{c}P(\text { elim }), 5 \\
\text { weeks } \\
\text { after end } \\
\text { of } A L 3\end{array}$ \\
\hline Actual & 15-Mar & $\begin{array}{l}\text { 19- } \\
\text { Mar }\end{array}$ & $\begin{array}{l}\text { 25- } \\
\text { Mar }\end{array}$ & $\begin{array}{l}\text { 13- } \\
\text { May }\end{array}$ & 84 & 25-Mar & 3 & 1503 & 22 & - \\
\hline 0 & 15-Mar & 19-Mar & 25-Mar & $\begin{array}{l}\text { 13- } \\
\text { May }\end{array}$ & $80[67,99]$ & $\begin{array}{l}\text { 31-Mar [26- } \\
\text { Mar, 02-Apr] }\end{array}$ & $4[1,8]$ & $1448[1208,1796]$ & $23[14,33]$ & 0.66 \\
\hline 1 & 15-Mar & 19-Mar & 20-Mar & 8-May & $69[61,79]$ & $\begin{array}{c}\text { 26-Mar [25- } \\
\text { Mar, 26-Mar] }\end{array}$ & $4[1,7]$ & $953[839,1132]$ & $14[8,21]$ & 0.63 \\
\hline $2 \mathrm{a}$ & 15-Mar & 19-Mar & 30-Mar & $\begin{array}{l}18- \\
\text { May }\end{array}$ & $108[84,139]$ & $\begin{array}{c}\text { 06-Apr [01-Apr, } \\
\text { 09-Apr] }\end{array}$ & $7[3,12]$ & $2373[1918,2999]$ & $39[26,55]$ & 0.57 \\
\hline $2 b$ & 15-Mar & 19-Mar & 4-Apr & $\begin{array}{l}23- \\
\text { May }\end{array}$ & $179[137,233]$ & $\begin{array}{c}\text { 11-Apr [09-Apr, } \\
\text { 14-Apr] }\end{array}$ & $12[6,19]$ & $3988[3161,5115]$ & $67[48,91]$ & 0.38 \\
\hline $2 \mathrm{c}$ & 15-Mar & 19-Mar & 14-Apr & $\begin{array}{l}28- \\
\text { May }\end{array}$ & $503[382,661]$ & $\begin{array}{c}\text { 21-Apr [20-Apr, } \\
\text { 23-Apr] }\end{array}$ & $\begin{array}{c}34[22, \\
49]\end{array}$ & $11534[8854,15048]$ & $200[147,266]$ & 0.07 \\
\hline 3 & 10-Mar & 19-Mar & 25-Mar & $\begin{array}{l}\text { 13- } \\
\text { May }\end{array}$ & $79[67,97]$ & $\begin{array}{c}\text { 31-Mar [26- } \\
\text { Mar, 02-Apr] }\end{array}$ & $4[1,8]$ & $1422[1194,1765]$ & $22[14,32]$ & 0.66 \\
\hline 4 & 15-Mar & 24-Mar & 25-Mar & $\begin{array}{l}13- \\
\text { May }\end{array}$ & $91[77,110]$ & $\begin{array}{l}\text { 01-Apr [31-Mar, } \\
\text { 02-Apr] }\end{array}$ & $5[1,9]$ & $1594[1359,1934]$ & $25[16,35]$ & 0.55 \\
\hline $5 \mathrm{a}$ & 10-Mar & 19-Mar & 20-Mar & 8-May & $68[61,79]$ & $\begin{array}{c}\text { 26-Mar [25- } \\
\text { Mar, 26-Mar] }\end{array}$ & $4[1,7]$ & $941[826,1119]$ & $14[8,21]$ & 0.63 \\
\hline $5 b$ & 15-Mar & 24-Mar & 30-Mar & $\begin{array}{l}18- \\
\text { May }\end{array}$ & $120[97,152]$ & $\begin{array}{c}\text { 06-Apr [01-Apr, } \\
\text { 08-Apr] }\end{array}$ & $7[3,12]$ & $2501[2069,3121]$ & $41[28,56]$ & 0.53 \\
\hline \multirow{2}{*}{6} & \multirow{2}{*}{ 15-Mar } & \multirow{2}{*}{ 19-Mar } & \multirow{2}{*}{ - } & & \multirow[b]{2}{*}{$\begin{array}{c}47592[47240, \\
47962]\end{array}$} & \multirow[b]{2}{*}{$\begin{array}{c}\text { 14-Jun [11-Jun, } \\
\text { 17-Jun] }\end{array}$} & \multirow[b]{2}{*}{$\begin{array}{c}1127[841 \\
1492]^{1}\end{array}$} & $\begin{array}{c}60443[45761 \\
79201]^{2}\end{array}$ & $1187[891,1565]^{2}$ & \multirow{2}{*}{$0.00^{4}$} \\
\hline & & & & & & & & $\begin{array}{c}1,812,900[1,809,600, \\
1,816,300]^{3}\end{array}$ & $\begin{array}{c}31905[31606 \\
32204]^{3}\end{array}$ & \\
\hline
\end{tabular}

${ }^{1}$ Evaluated on 27 th April 2020 (end of actual AL4); continues to increase after this date.

${ }^{2}$ Evaluated on 13th May 2020 (end of actual AL3); continues to increase after this date.

${ }^{3}$ Evaluated at end of outbreak. Across all realisations, the outbreak had run its full course by approx. October 2020, on average, and the last case reported by 20 December 2020 at the latest.

${ }^{4}$ Evaluated on 18th June 2020 (5 weeks after end of actual AL3). 
medRxiv preprint doi: https://doi.org/10.1101/2020.10.20.20216457; this version posted March 22, 2021. The copyright holder for this preprint (which was not certified by peer review) is the author/funder, who has granted medRxiv a license to display the preprint in

It is made available under a CC-BY-NC-ND 4.0 International license .
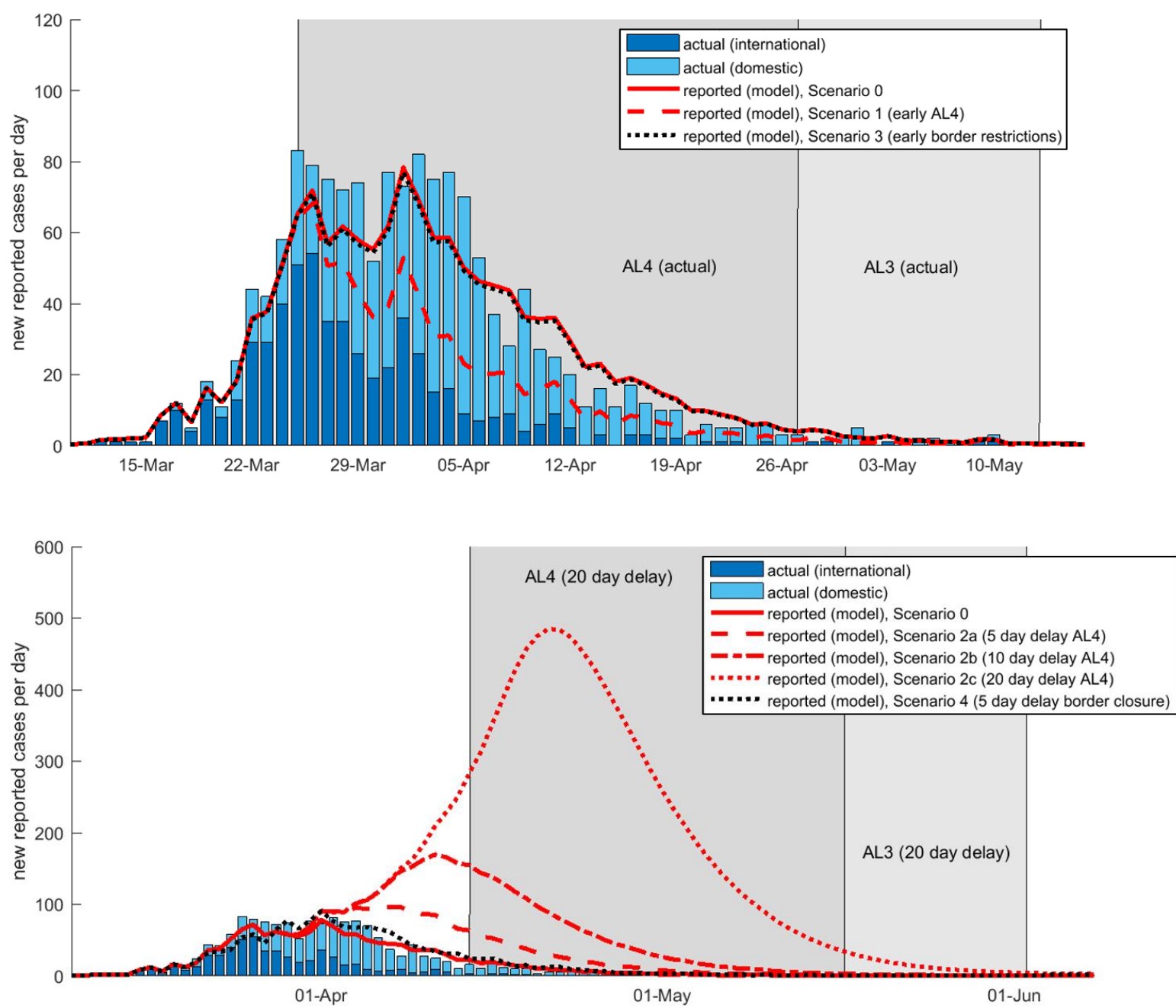

396

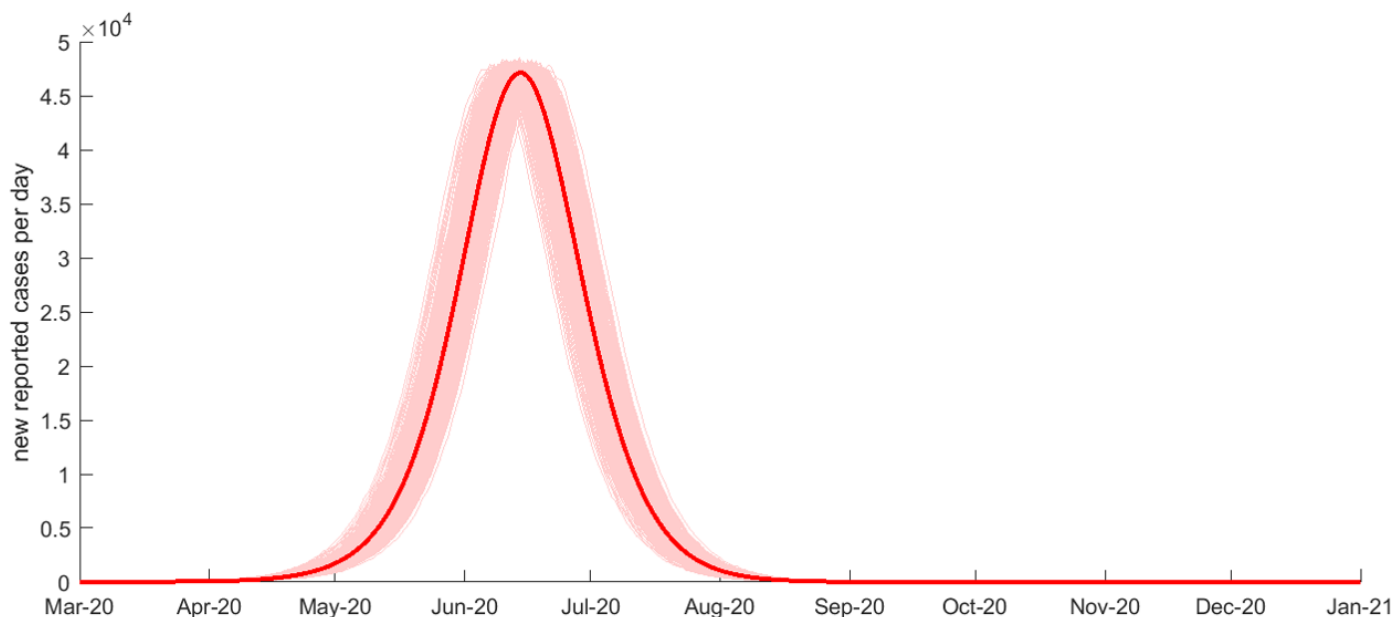

Figure 1: Effect of alternative timings of interventions on the trajectory of the outbreak. Number of new reported cases per day predicted by the model alongside observed reported domestic (light blue bars) and international cases (dark blue bars) (data source: $\mathrm{MoH}$ ). Model simulated for interventions implemented on their actual start dates and for alternative scenarios with different timings of ALA, border restrictions or border closure Top: Scenarios with AL4 started 5 days early (border restrictions and closure on actual start dates) (red dashed; Scenario 1) compared with a scenario where border restrictions were implemented five days early (border closure on actual start date) (red dotted; Scenario 
medRxiv preprint doi: https://doi.org/10.1101/2020.10.20.20216457; this version posted March 22, 2021. The copyright holder for this preprint (which was not certified by peer review) is the author/funder, who has granted medRxiv a license to display the preprint in It is made available under a CC-BY-NC-ND 4.0 International license.

3). Middle: Delayed start to Alert Level 4 (delays of 5, 10 and 20 days; Scenarios 2a-c; red broken lines) (with border restrictions and closure on actual start dates). Five day delay to border closure (with border restrictions and AL4 on actual start dates) (black dotted line; Scenario 4). Bottom: No ALA/3 restrictions (border restrictions and closure on actual start dates; Scenario 6) results in an uncontrolled outbreak; faint red lines show the outbreak in individual realisations of the model, bold red line is the average over all 5000 simulations. Note, y-axis scale differs between figures.

\section{Scenario 2: Delayed AL4}

Delaying the move into Alert Level 4 would have led to a higher peak in daily new cases, and greater cumulative totals of cases and deaths. For a delay of 20 days (Scenario 2c), the outbreak would have reached a considerably higher maximum of close to 500 daily new cases (cf. 80 cases in Scenario 0; Table 2, Fig. 1 and Fig. 2). This number would certainly have overwhelmed the contact tracing system, which was already pushed close to capacity in places by the 70-80 daily new cases in late March (Verrall, 2020). After a week in AL4, case numbers would start to decline and by the end of the 4 weeks in AL4 daily new cases would still have been as high as $34[22,49]$ (close to the actual number of domestic daily reported cases when New Zealand went into AL4 on 25 March). By the end of the 7 week period of stringent restrictions (i.e. end of AL3) the incidence would have dropped to approximately 4 new cases per day (Fig. 1), but the cumulative total could have climbed to $11,534[8854,15048]$ reported cases and $200[147$, 266] deaths, substantially more than Scenario 0 and the 1,503 cases and 22 deaths actually reported on 13 May. Additionally, the probability of elimination 5 weeks after the end of AL3 was only 7\%, much lower than in Scenario 0.

\section{Scenario 3: Early border restrictions}

We next investigated a scenario where border restrictions were put in place 5 days earlier, but border closure and AL4 were started on their actual dates. Border restrictions would therefore have been in place for 9 days (cf. actual 4 days) before the border was closed. Our model 
medRxiv preprint doi: https://doi.org/10.1101/2020.10.20.20216457; this version posted March 22, 2021. The copyright holder for this preprint (which was not certified by peer review) is the author/funder, who has granted medRxiv a license to display the preprint in It is made available under a CC-BY-NC-ND 4.0 International license .

predicted this would have had very little impact for the initial trajectory (Fig. 1) or eventual outbreak size, with values for all key measures similar to those in Scenario 0 (Table 2). This suggests that key measures are more sensitive to varying the timing of AL4 than to the timing of border restrictions. In reality, out of the 563 international cases who arrived prior to the start of MIQ and could have contributed to local transmission, only 78 (14\%) arrived before border restrictions were implemented on 15 March and were not required to self-isolate. Furthermore, out of these 78 cases, 52 arrived between 10 and 15 March and 19 of these were reported to have voluntarily self-isolated immediately on arrival (the model simulates these 19 cases as being self-isolated on arrival in all scenarios). Therefore, under this scenario, early selfisolation requirements reduce transmissions by a factor $c_{i s o}=0.65$ (Appendix Table S1) for only an additional 33 international cases. This reduction is not sufficient to prevent an outbreak, nor does it reduce transmission to an extent where AL4/3 restrictions would not have been necessary to control the outbreak. In contrast, starting AL4 early (Scenario 1) has a stronger effect because it substantially reduces transmissions by a factor $C(t)=0.15$ (Appendix Table S1) for all locally acquired cases (clinical and subclinical) and international cases.

\section{Scenario 4: Delayed border closure}

Under a scenario where closure of the border (to all except returning residents and citizens) was delayed by 5 days (24 March; 9 days after border restrictions and 1 day before AL4), our model predicted slightly worse outcomes, on average, for key measures compared to Scenario 0 . However, due to the stochasticity of individual simulations, the range of key measures always had overlap with the Scenario 0 values and actual values, suggesting a 5 day delay to border closure alone would not have made a significant difference. A delayed border closure did, however, have a greater impact for the probability of elimination 5 weeks after AL3 restrictions were relaxed, which was only 55\%, compared to $66 \%$ in Scenario 0 . This reduced 
medRxiv preprint doi: https://doi.org/10.1101/2020.10.20.20216457; this version posted March 22, 2021. The copyright holder for this

preprint (which was not certified by peer review) is the author/funder, who has granted medRxiv a license to display the preprint in It is made available under a CC-BY-NC-ND 4.0 International license .

probability of elimination is partly due to the additional international clinical cases (captured in the key measures of reported cases) and international subclinicals (not captured in reported cases) arriving prior to the delayed border closure. It is also likely affected by the international case outlier with the pre-MIQ arrival date and late onset date, discussed above.

\section{Scenario 5: Change in timing of ALA, border restrictions and closure}

After varying the timing of interventions individually, we considered the effects of varying timings for two interventions. If border restrictions were implemented 5 days early and AL4 came into effect 5 days early (Scenario $5 \mathrm{a}$ ), this would have led to outcomes very similar to those predicted in Scenario 1 (where only AL4 started early) (Table 2). This again suggests that results are more sensitive to changes in timing for the start of AL4 than to an earlier start to border restrictions.

The outcomes from delaying both border closure and the start of AL4 by 5 days (Scenario $5 b$ ) were similar to a 5-day delay to AL4 (Scenario 2a), though slightly worse due to the combined effect of delays to both interventions. Therefore, the timing of AL4 also appears to have a greater impact than timing of border closure. Compared to the factual Scenario 0, daily new cases would have reached a larger maximum of $120[97,152]$ cases on 6 April and by the end of the 7 week period in AL4/3 there would have been close to 1,050 more cases in total and nearly 20 more deaths (Table 2). The probability of elimination 5 weeks after AL3 would have also been reduced to $53 \%$.

\section{Scenario 6: No AL4}

Finally, we explored the impact of only having border restrictions and border closure in place, but without implementing AL4/3. Under this scenario, the international cases who arrived prior 
medRxiv preprint doi: https://doi.org/10.1101/2020.10.20.20216457; this version posted March 22, 2021. The copyright holder for this preprint (which was not certified by peer review) is the author/funder, who has granted medRxiv a license to display the preprint in It is made available under a CC-BY-NC-ND 4.0 International license .

to 9 April and were either in self-isolation or were not isolated have a chance of seeding an outbreak which, without AL4/3 measures to reduce $R_{\text {eff }}$ below one, leads to community transmission and a large uncontrolled outbreak. New Zealand would have seen close to 1127 [841, 1492] new cases per day by 27 April, the date on which New Zealand moved from AL4 to AL3 in reality. By 13 May (the date on which New Zealand moved from AL3 to AL2), there could have been over 60,000 cumulative reported cases and over 1100 deaths. New cases would have continued to increase, reaching a peak of 47,592 [47,240, 47,962] daily new cases on 14 June (Table 2). By the end of the outbreak, around October 2020 on average, there could have been over 1.81 million reported cases in total and 31,905 [31,606, 32,204] deaths. No simulations resulted in elimination by 18 June (5 weeks after end of actual AL3), indicating a $0 \%$ chance of COVID-19 having been eliminated by this time, compared to the $66 \%$ chance on this date in Scenario 0. This is an important result demonstrating that border measures alone would have been insufficient to prevent a serious outbreak from occurring and that stringent AL4/3 restrictions were necessary to have a chance of eliminating community transmission.

\section{Sensitivity analysis}

We assessed the effect that different lengths of delay (in days) until the start of AL4 (Fig. 2) had on key measures: maximum load on contact tracing system; cumulative total reported cases; total infected cases (including both clinical and subclinical); total deaths at end of AL3; and probability of elimination 5 weeks after the end of AL3. Measures of numbers of cases and deaths increased exponentially with increasing delay to AL4, emphasising the importance of acting quickly to reduce the risk of large outbreaks arising. Probability of elimination decreased linearly with increasing delays to AL4. Counter-intuitively, earlier starts to AL4 slightly reduced the probability of elimination; again, this is caused by the international case outlier 
medRxiv preprint doi: https://doi.org/10.1101/2020.10.20.20216457; this version posted March 22, 2021. The copyright holder for this preprint (which was not certified by peer review) is the author/funder, who has granted medRxiv a license to display the preprint in perpetuity.
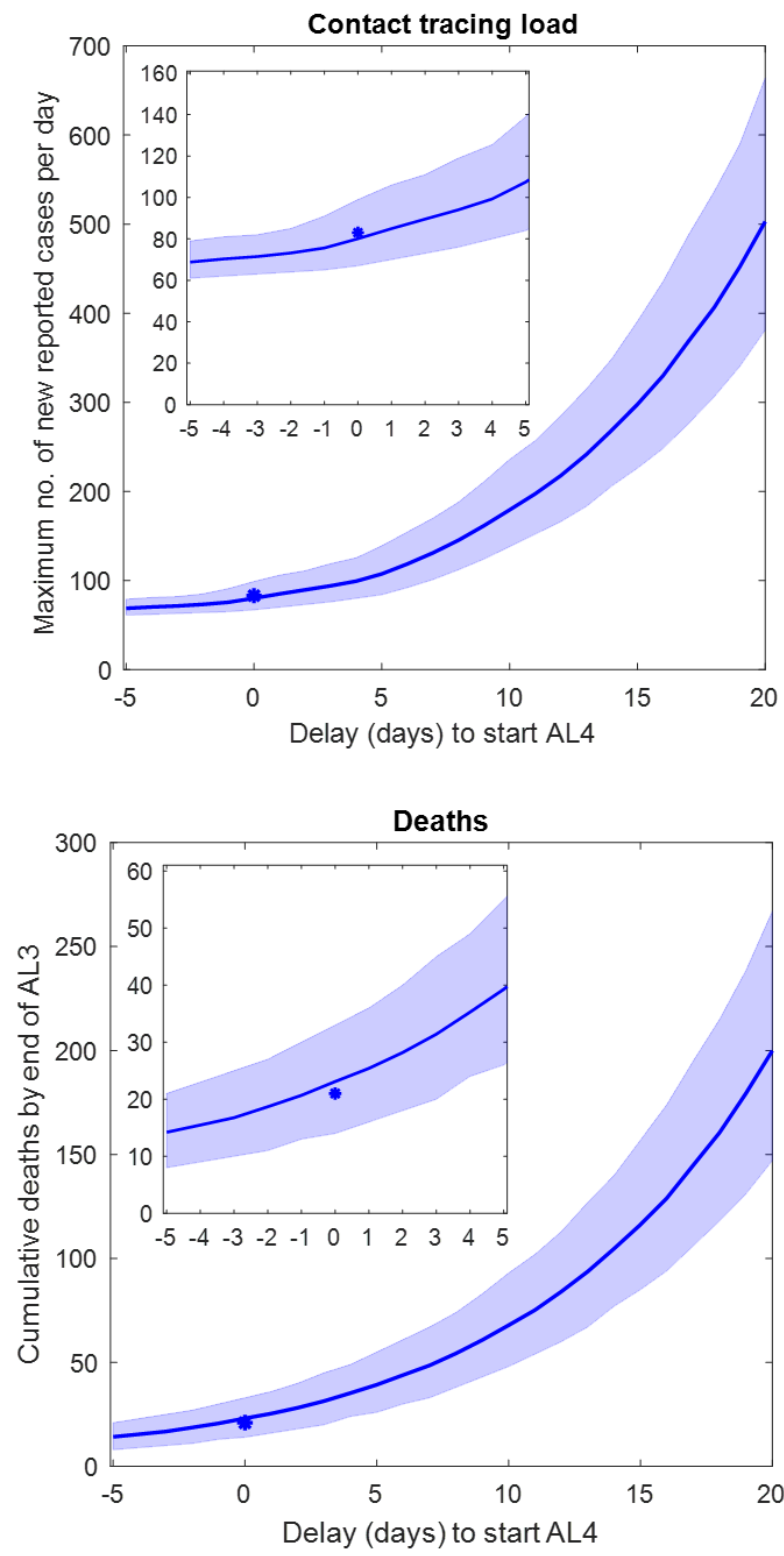
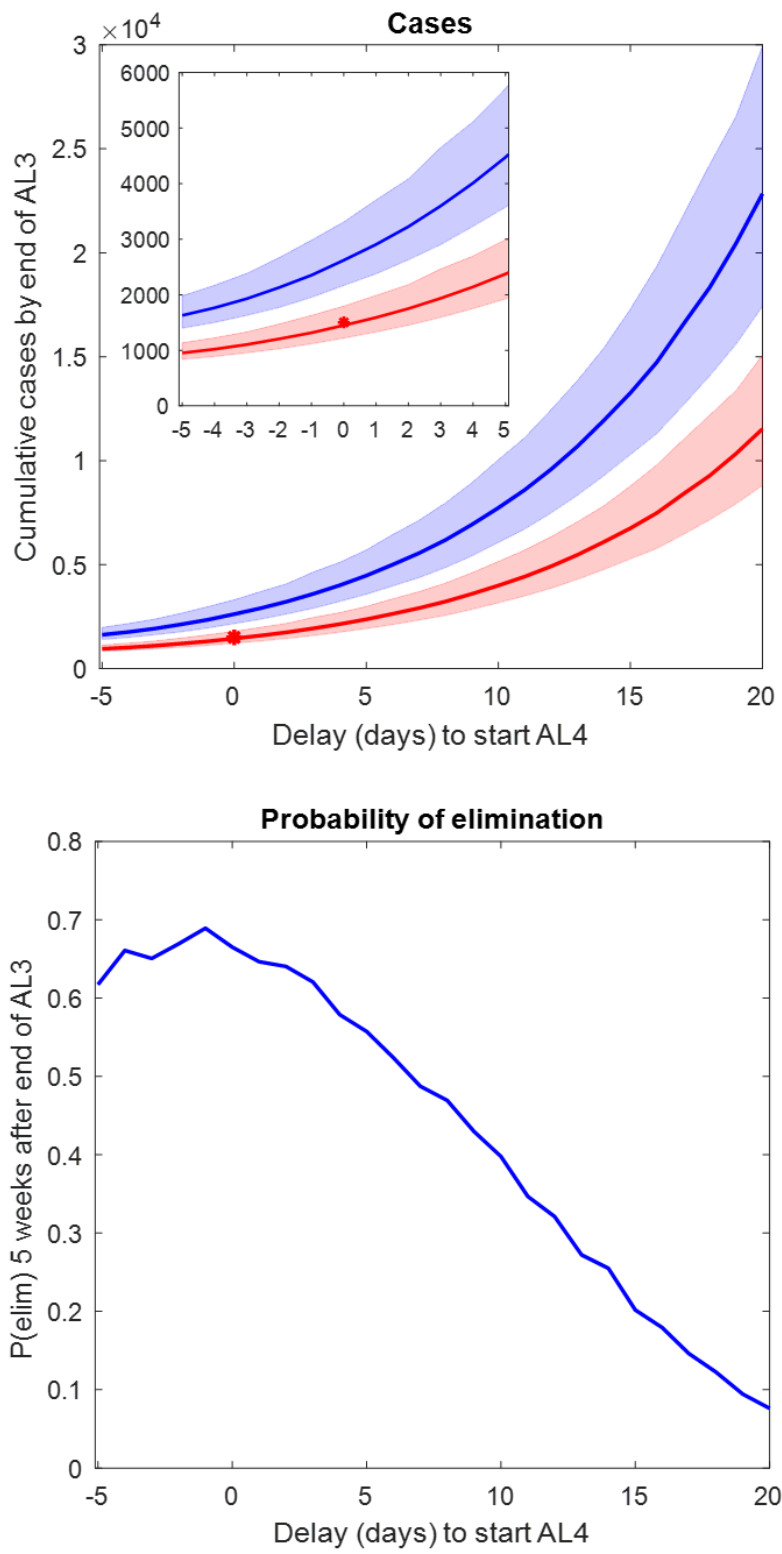

discussed previously. If the outlier is excluded from the international case data, the predicted probability of elimination is insensitive to AL4 starting 1 to 5 days early. 
medRxiv preprint doi: https://doi.org/10.1101/2020.10.20.20216457; this version posted March 22, 2021. The copyright holder for this preprint (which was not certified by peer review) is the author/funder, who has granted medRxiv a license to display the preprint in It is made available under a CC-BY-NC-ND 4.0 International license .

of AL3. Shaded regions indicate the interval range in which $90 \%$ of simulation results are contained. Note, y-axis scale differs between figures. Insets show close-ups of results for delays from -5 to 5 days.

Introducing border restrictions ten days earlier still results in an outbreak and gives very similar results to Scenario 3 (5 days early), with a maximum of $77[65,94]$ new daily cases, 1385 $[1166,1706]$ cumulative reported cases at the end of AL3, $P($ elim $)=0.68$, and other measures the same as in Scenario 3. With border restrictions ten days earlier, the only difference compared to Scenario 3 is that an additional 16 cases who arrived between 5 and 10 March have their transmission rates reduced (a further 2 cases arriving in this 5-day period were voluntarily self-isolated on arrival in reality, so are simulated with self-isolation on arrival in all scenarios). This has little impact on the overall contribution to local transmission by all 563 international cases who arrive prior to the start of MIQ, providing further support that border restrictions alone are less effective at reducing community transmission compared to stringent Alert Level restrictions.

We also tested the sensitivity of all key measures to using different values of $R_{\text {eff }}$ under AL3 (Table S3; $R_{\text {eff }}=1.1,0.95$ and 0.7). Different choices of AL3 $R_{\text {eff }}$ had very little effect on predicted cumulative totals of cases at the end of AL3 and no effect on total deaths at end of AL3. However, the predicted probability of elimination was sensitive to varying AL3 $R_{\text {eff }}$; for all scenarios, assuming a lower $R_{\text {eff }}=0.7$ (more effective AL3) gave a $P($ elim) that was approximately 0.14 higher than with $R_{\text {eff }}=0.95$, while a higher $R_{\text {eff }}=1.1$ (less effective AL3) reduced $P($ elim $)$ by approximately 0.07 . This did not affect our general conclusion that the timing of AL4 has a greater impact on key measures than timing of border measures. 
medRxiv preprint doi: https://doi.org/10.1101/2020.10.20.20216457; this version posted March 22, 2021. The copyright holder for this

preprint (which was not certified by peer review) is the author/funder, who has granted medRxiv a license to display the preprint in It is made available under a CC-BY-NC-ND 4.0 International license .

\section{Discussion}

New Zealand's decision to act quickly and to implement stringent restrictions to reduce SARSCoV-2 transmission meant that, to date, New Zealand has experienced amongst the lowest mortality rates reported worldwide (Kontis et al., 2020). On 8 June 2020, nearly 11 weeks after AL4 was initiated, New Zealand declared elimination of COVID-19. Over the course of the March-April outbreak, a total of 1504 cases and 22 deaths were reported before elimination was achieved. Our results suggest that the timing of Alert Level 4 is a much stronger driver of reductions in daily new cases than timings of border restrictions and closure. This finding makes sense because the effect of AL4 in the model is to greatly reduce $R_{\text {eff }}$ for all cases, domestic and international arrivals, to 0.35 , while border restrictions reduce the delay until case isolation of international cases only (i.e. international cases have their transmission rates reduced earlier) and border closure reduces the daily numbers of international cases only. Out of the scenarios we considered, an earlier start to AL4 by 5 days resulted in the greatest reduction in numbers of cases and deaths, with approximately 500 fewer cases in total and 10 fewer deaths. However, in reality, the rapid escalation of the COVID-19 situation in mid-March may have made an earlier start to AL4 impractical and would have allowed less time to prepare for ongoing provision of essential services under AL4.

Introducing border restrictions requiring 14-day self-isolation for international arrivals earlier than 15 March would have been unlikely to have much impact on the trajectory of New Zealand's March-April outbreak, unless such measures were started prior to the first case on 26 February and used methods that were particularly effective (notably full MIQ). The 563 international cases arriving between 15 March and 9 April were already required to self-isolate; had border restrictions been in place prior to the arrival of New Zealand's first case, this would 
medRxiv preprint doi: https://doi.org/10.1101/2020.10.20.20216457; this version posted March 22, 2021. The copyright holder for this preprint (which was not certified by peer review) is the author/funder, who has granted medRxiv a license to display the preprint in It is made available under a CC-BY-NC-ND 4.0 International license .

have required self-isolation for, at most, an additional 56 international cases (22 cases who arrived prior to 15 March self-isolated voluntarily immediately on their arrival). In mid-March, there was a lower global prevalence of COVID-19 and between 2 and 12 cases arrived at the border each day in the week prior to 15 March. With a higher global prevalence and correspondingly higher numbers of international cases arriving per day, earlier implementation of border restrictions may have had a greater impact than our model predicted for this outbreak. Self-isolation is less stringent than MIQ and relies heavily on public compliance. Without additional safety nets, such as official monitoring and support for people who are self-isolating, there is a greater risk of the virus spreading into the community than in MIQ facilities. For example, risk of non-compliance may be higher for individuals who are concerned about loss of income (Bodas \& Peleg, 2020). Without Alert Level restrictions in place to require strong community-wide social distancing, any infected individuals who do not self-isolate effectively are more likely to spark an outbreak. Self-isolation restrictions for international arrivals can therefore reduce the frequency of cases leaking into the community (James et al, 2020c) but are unlikely to be sufficient to prevent an outbreak entirely, unless additional measures are also put in place.

Delaying border closure by 5 days could have led to a slightly larger outbreak, but not as large as if AL4 had been delayed by 5 days. The full effect on local transmission potential of the additional international cases expected under a delayed border closure was partially dampened because international cases arriving after 9 April were still placed in MIQ and assumed not to contribute to community transmission. If the timing of this MIQ policy was also delayed, a larger outbreak may have occurred, but we did not model such a scenario here. If the start of AL4 had been delayed by 20 days, our results suggest New Zealand could have experienced over 11,500 reported cases and 200 deaths, reducing the chance of elimination to only $7 \%$. As 
medRxiv preprint doi: https://doi.org/10.1101/2020.10.20.20216457; this version posted March 22, 2021. The copyright holder for this

preprint (which was not certified by peer review) is the author/funder, who has granted medRxiv a license to display the preprint in It is made available under a CC-BY-NC-ND 4.0 International license .

610

with other severe viral disease, the infection fatality risk for COVID-19 is greater for Māori and Pacific peoples (close to 50\% higher for Māori than for non-Māori) (Steyn et al., 2020; Wilson et al., 2012; Verrall et al., 2010). Therefore, in scenarios resulting in significantly higher numbers of COVID-19-related deaths (e.g. Scenario 2c), Māori and Pacific communities would likely have been disproportionately affected, however a populationstructured model would be required to assess this consequence in detail. Delaying AL4 would have also increased the chance of a longer lockdown period being required to reduce daily new case numbers to low levels. With a 20 day delay to AL4, New Zealand could still have been experiencing close to 35 new reported cases per day at the end of AL4. While in reality, a 33day period in AL4 was sufficient to reduce daily new cases to below 10, and the Government announced an easing to AL3, these higher case numbers predicted for a delayed start to AL4 may have motivated an extension to the lockdown to allow more time for cases to drop below a safe threshold.

In terms of the key measures we considered, the counterfactual scenario with no AL4/3 restrictions (Scenario 6) had disastrous outcomes, including close to 2 million reported cases and tens of thousands of deaths. This demonstrates that: 1) under the conditions (e.g. level of pandemic preparedness and global COVID-19 prevalence) particular to New Zealand's March - April outbreak, border restrictions and border closure alone would not have been sufficient to control the outbreak; and 2) New Zealand's national lockdown restrictions in combination with its border management, rapid testing and contact tracing, were effective measures that prevented a considerably larger and more prolonged outbreak (i.e. Scenario 6) from occurring during that period. 
medRxiv preprint doi: https://doi.org/10.1101/2020.10.20.20216457; this version posted March 22, 2021. The copyright holder for this preprint (which was not certified by peer review) is the author/funder, who has granted medRxiv a license to display the preprint in It is made available under a CC-BY-NC-ND 4.0 International license .

621 Our model uses a value of $R_{\text {eff }}=0.35$ during AL4, which was estimated by Binny et al (2020b)

622

623

624

625

626

627

628

629

630

631

632

633

634

635

636

637

638

639

640

641

642

643

644

645

by fitting the model to case data over the entire period under AL4, and is consistent with a later estimate of $R_{e f f}$ from reconstructions of the epidemiological tree (James et al., 2020c). This is a relatively low value of $R_{\text {eff }}$ compared to other countries who implemented interventions roughly equivalent to AL4 (Flaxman et al, 2020; Binny et al, 2020a). A combination of a highly effective social distancing in AL4, fast contact tracing, effective case isolation, and the fact that the outbreak occurred at the end of the Southern hemisphere summer, likely contributed to this low $R_{e f f}$ (James et al, 2020b). Disentangling the effects of different interventions introduced in quick succession is challenging (see e.g. Flaxman et al., 2020). For this reason, we apply a single $R_{\text {eff }}$ value for the period prior to AL4, rather than different values for the period prior to 21 March and the 2-day periods under AL2 and AL3. Due to the delays from exposure to symptom onset and to testing/reporting, AL2-3 likely contributed to the initial flattening in the curve of New Zealand's daily reported cases during the early phase of AL4. In the late phase of AL4, these lagged effects of AL2-3 would no longer be reflected in daily reported cases. Because our model explicitly accounts for the infection-to-onset and reporting delays, and our best-fit values were obtained by fitting to case data from the entire AL4 period, our estimate $R_{\text {eff }}=0.35$ for AL4 effectiveness is independent of the lagged effects of earlier interventions.

For scenarios where the load on contact tracing exceeded system capacity (e.g. Scenario 2c with a maximum 500 daily new cases), this effect would have likely resulted in longer delays to isolation of cases and a higher $R_{\text {eff }}$. We did not attempt to model this potential feedback effect and so our results for scenarios where contact tracing system capacity is exceeded may underestimate the outbreak size. Our model assumed a relatively high and constant proportion (75\%) of clinical cases are detected and reported. In reality, this proportion can vary over time as testing and contact tracing policies are revised, or as contact tracing and health systems 
medRxiv preprint doi: https://doi.org/10.1101/2020.10.20.20216457; this version posted March 22, 2021. The copyright holder for this preprint (which was not certified by peer review) is the author/funder, who has granted medRxiv a license to display the preprint in It is made available under a CC-BY-NC-ND 4.0 International license .

646 become overloaded in a large uncontrolled outbreak (e.g. Scenario 6). This makes it difficult

647 to benchmark predicted case numbers against empirical data from outbreaks in other countries,

648 where testing and contact tracing regimes may differ from New Zealand. Infection fatality rates

649 also vary between different countries and over time, for example fatality rates can decrease as

650 new knowledge, treatments and technologies become available. For simplicity, our model

651

652

653

654

655

656

657

658

659

660

661

662 assumed a constant IFR of $0.88 \%$, which is within the range of IFR estimates reported for other countries and very close to the median IFR reported for countries with COVID-19 mortality rates that are less than the global average (Ioannidis, 2020). We did not attempt to directly model the burden of COVID-19 on the healthcare system (e.g. numbers of cases requiring hospitalisation or intensive care), or the effects of an overwhelmed healthcare system. Once numbers of daily new cases requiring hospitalisation or ICU admission exceed New Zealand's healthcare system capacity, this could result in increased fatality rates and considerably more deaths (Hendy et al., 2021). These effects would have been most pronounced under the scenario with no AL4/3 restrictions.

While we report average values for outbreak dynamics, each individual realisation of the stochastic model can deviate (sometimes widely) from the average behaviour. When case numbers are small, as they were in New Zealand, the predicted dynamics are particularly sensitive to fine-scale variations. While $R_{\text {eff }}<1$ means that an outbreak will eventually die out, on average, it is still possible for a small number of cases to spark an outbreak in a particular stochastic realisation if interventions are relaxed too soon. Conversely, when case numbers are small, an outbreak can still die out by chance even when $R_{\text {eff }}>1$. It is therefore important to account for this stochasticity when weighing the effectiveness and risks of different intervention strategies, for example by considering the probability of elimination. On 18 June, five weeks after AL3 restrictions were relaxed, the probability that community transmission of 
medRxiv preprint doi: https://doi.org/10.1101/2020.10.20.20216457; this version posted March 22, 2021. The copyright holder for this preprint (which was not certified by peer review) is the author/funder, who has granted medRxiv a license to display the preprint in It is made available under a CC-BY-NC-ND 4.0 International license .

671 COVID-19 had been eliminated in model simulations was estimated to be $66 \%$ in Scenario 0.

672 This estimate is calculated by finding the proportion of stochastic realisations that resulted in

673 elimination. In reality, as the outbreak died out and more days with zero new cases were

674 observed, this provided additional information about which trajectory New Zealand was most

675 likely experiencing. Each additional consecutive day with no new reported cases reduced the

676 likelihood of being on an upward trajectory. Making use of this additional information meant

677 that New Zealand's estimated probability of elimination on 18 June, given there had been 27

678 consecutive days with zero new cases reported, was approximately 95\%, higher than in

679 Scenario 0 (Binny et al., 2020c). However, this estimate required up-to-date information about

680 recent case numbers. The results reported in this paper compare average outcomes under

681

682

683

684

685

686

687

688

689

690

691

692

693

694

695 different scenarios, which is appropriate for evaluating the effect of alternative actions and guiding future decision making. In general, for the other scenarios we explored, bringing in earlier interventions had very little impact on probability of elimination, while delaying border closure or AL4 reduced the chance of elimination. Definitions of the end of an outbreak and approaches to inferring probability of elimination from incidence data vary between studies. Estimates can be highly sensitive to $R_{\text {eff }}$ (Djaafara et al., 2020) and to surveillance factors, including the degree of time-varying under-reporting, reporting delays, and the interaction of local and imported cases (Parag et al., 2020). Our estimates of $P(\mathrm{elim})$ are sensitive to changes in model parameters that result in changes to $R_{\text {eff }}$, however this does not affect our overall conclusions that timing of AL4 is more important for controlling the outbreak than timing of border measures, and that border measures alone are insufficient.

Our results are important for reflecting on the effectiveness of intervention timing in New Zealand's COVID-19 response, relative to alternative scenarios, to help guide future response strategies. Early intervention was critical to the successful control of New Zealand's March- 
medRxiv preprint doi: https://doi.org/10.1101/2020.10.20.20216457; this version posted March 22, 2021. The copyright holder for this preprint (which was not certified by peer review) is the author/funder, who has granted medRxiv a license to display the preprint in It is made available under a CC-BY-NC-ND 4.0 International license .

696 April outbreak. For modelling future disease outbreaks, epidemiological parameters should be updated to reflect changes in national pandemic preparedness (e.g. improved policy and response plans) and behavioural changes influencing the dynamics of future outbreaks. For instance, the degree of compliance with alert level restrictions in future may differ dramatically from the March-April outbreak, resulting in different values of $R_{\text {eff. }}$. Further work is needed to explore the social dynamics affecting transmission and the effectiveness of interventions, for instance whether wearing masks in public spaces becomes more common, or whether more people will choose to work from home or avoid travel if a suspected new outbreak is reported or if government action is perceived to be inadequate.

The key measures of outbreak dynamics assessed here should be considered alongside other measures of economic, social and health impacts (e.g. job losses, consumer spending, impacts for mental health, rates of domestic violence or disrupted education). Particular attention needs to be given to identifying vulnerable groups who may experience inequitable impacts so that future policies can be tailored to support these groups. At the end of AL3, health benefits (e.g. number of cases and deaths avoided) differed between scenarios. For cost-benefit analyses, age-dependent morbidity and mortality rates of COVID-19 (Kang \& Jung, 2020) allow numbers of cases and deaths to be quantified in terms of disability-adjusted life years (DALYs) avoided (or quality-adjusted life years gained), which can (with obvious issues) be converted to monetary units to facilitate comparison with economic costs. Because the duration spent under AL4/AL3 was fixed at 7 weeks for Scenarios 0-5, the short-term economic costs of the different scenarios would have been similar, so we did not convert health benefits into DALYs here. After the end of AL3, benefits and costs would differ between scenarios depending on the value of $R_{\text {eff }}$ for AL1-2 and on whether or not elimination was achieved. Increased levels of activity and contact rates under AL1-2 mean that $R_{\text {eff }}$ is very likely to have been greater than 
medRxiv preprint doi: https://doi.org/10.1101/2020.10.20.20216457; this version posted March 22, 2021. The copyright holder for this preprint (which was not certified by peer review) is the author/funder, who has granted medRxiv a license to display the preprint in It is made available under a CC-BY-NC-ND 4.0 International license .

one. In scenarios with lower probabilities of elimination, it is more likely that New Zealand would continue to experience new cases while under AL1-2 which, with $R_{\text {eff }}>1$, would likely lead to another outbreak and require a second lockdown (with its associated costs). Conversely, scenarios with higher probabilities of elimination mean there is a greater chance of the outbreak dying out entirely and less risk of a second lockdown being required. Future work could consider the costs and benefits of alternative scenarios where the duration of time spent in AL4 and AL3 is dictated by the need to achieve a certain threshold probability of elimination.

\section{Acknowledgements}

The authors acknowledge the support of StatsNZ, ESR, and the Ministry of Health in supplying data in support of this work. We are grateful to Samik Datta, Nigel French, Markus LuczakRoesch, Melissa McLeod, Anja Mizdrak, Fraser Morgan and Matt Parry for comments on an earlier version of this manuscript. This work was funded by the Ministry of Business, Innovation and Employment and Te Pūnaha Matatini, a New Zealand Centre of Research Excellence.

\section{References}

Baker MG, Kvalsvig A, Verrall AJ (2020a). New Zealand's COVID-19 elimination strategy. The Medical Journal of Australia, 213(5):198-200.e1, doi:10.5694/mja2.50735

Baker MG, Kvalsvig A, Verrall AJ, Telfar-Barnard L, Wilson N (2020b). New Zealand's elimination strategy for the COVID-19 pandemic and what is required to make it work. The New Zealand Medical Journal (Online), 133(1512):10-4. 
medRxiv preprint doi: https://doi.org/10.1101/2020.10.20.20216457; this version posted March 22, 2021. The copyright holder for this preprint (which was not certified by peer review) is the author/funder, who has granted medRxiv a license to display the preprint in It is made available under a CC-BY-NC-ND 4.0 International license .

Baker MG, Wilson N, Anglemyer A (2020c). Successful elimination of covid-19 transmission in New Zealand. New England Journal of Medicine, 383:e56, doi: $\underline{10.1056 / \mathrm{NEJMc} 2025203}$

Binny RN, Hendy SC, James A, Lustig A, Plank MJ, Steyn N (2020a). Effect of Alert Level 4 on effective reproduction number: review of international COVID-19 cases. medRxiv preprint, doi: 10.1101/2020.04.30.20086934

Binny RN, Lustig A, Brower A, Hendy SC, James A, Parry M, Plank MJ, Steyn N (2020b). Effective reproduction number for COVID-19 in Aotearoa New Zealand. medRxiv preprint, doi: 10.1101/2020.08.10.20172320

Binny RN, Hendy SC, James A, Lustig A, Plank MJ, Steyn N (2020c). Probability of elimination for COVID-19 in Aotearoa New Zealand. medRxiv preprint, doi: $\underline{10.1101 / 2020.08 .10 .20172361}$

Bodas M \& Peleg K (2020). Self-Isolation compliance in the COVID-19 era influenced by compensation: findings from a recent survey in Israel. Health Affairs, 39(6):936-941, doi:

$\underline{10.1377 / \text { hlthaff.2020.00382 }}$

Brauner JM, Mindermann S, Sharma M, et al. (2020). The effectiveness of eight nonpharmaceutical interventions against COVID-19 in 41 countries. medRxiv preprint, doi: $10.1101 / 2020.05 .28 .20116129$

[DPMC] Department of Prime Minister and Cabinet (2020). CAB-20-SUB-0270 Review of COVID-19 Alert Level 2, 8 June 2020. Proactive release. url: https://covid19.govt.nz/assets/resources/proactive-release-2020-july/AL2-Minuteand-Paper-CAB-20-MIN-0270-Review-of-COVID-19-Alert-Level-2-8-June2020.PDF (accessed 9 September 2020) 
medRxiv preprint doi: https://doi.org/10.1101/2020.10.20.20216457; this version posted March 22, 2021. The copyright holder for this preprint (which was not certified by peer review) is the author/funder, who has granted medRxiv a license to display the preprint in It is made available under a CC-BY-NC-ND 4.0 International license .

Davies NG, Kucharski AJ, Eggo RM, Gimma A, Edmunds WJ, CMMID COVID-19 Working Group, (2020). Effects of non-pharmaceutical interventions on COVID-19 cases, deaths and demand for hospital services in the UK: a modelling study. The Lancet. Public Health, 5(7):e375-e385, doi: 10.1016/s2468-2667(20)30133-x

Desvars-Larrive A, Ahne V, Álvarez S, et al. (2020). CCCSL: Complexity Science Hub Covid19 Control Strategies List. Version 2.0. Available from: https://github.com/amelgithub/covid19-interventionmeasures (accessed 20 August 2020)

Djaafara BA, Imai N, Hamblion E, Impouma B, Donnelly CA, Cori A (2020). A Quantitative Framework for Defining the End of an Infectious Disease Outbreak: Application to Ebola Virus Disease. American Journal of Epidemiology, kwaa212, doi: 10.1093/aje/kwaa212.

Ferretti L, Wymant C, Kendall M, Zhao L, Nurtay A, Abeler-Dörner L, Parker M, Bonsall D, Fraser C (2020). Quantifying SARS-CoV-2 transmission suggests epidemic control with digital contact tracing. Science, 368(6491):eabb6936, doi: https://doi.org/10.1126/science.abb6936

Flaxman S, Mishra S, Gandy A, et al. (2020). Estimating the effects of non-pharmaceutical interventions on COVID-19 in Europe. Nature, 584:257-261, doi: 10.1038/s41586$\underline{020-2405-7}$

Hendy SC, Steyn N, James A, Plank MJ, Binny RN, Lustig A (2021). Mathematical modelling to inform New Zealand's COVID-19 response. Journal of the Royal Society of New Zealand, doi: 10.1080/03036758.2021.1876111

Hsiang S, Allen D, Annan-Phan S, et al. (2020). The Effect of Large-Scale Anti-Contagion Policies on the Coronavirus (COVID-19) Pandemic. medRxiv preprint, doi: $\underline{10.1101 / 2020.03 .22 .20040642}$ 
medRxiv preprint doi: https://doi.org/10.1101/2020.10.20.20216457; this version posted March 22, 2021. The copyright holder for this preprint (which was not certified by peer review) is the author/funder, who has granted medRxiv a license to display the preprint in It is made available under a CC-BY-NC-ND 4.0 International license .

814

Ioannidis JPA (2020). Infection fatality rate of COVID-19 inferred from seroprevalence data. Bulletin of the World Health Organization. Early access online, url: https://www.who.int/bulletin/online_first/BLT.20.265892.pdf (accessed 4 November 2020)

James A, Plank MJ, Binny RN, Hannah K, Hendy SC, Lustig A, Steyn N (2020a). A structured model for COVID-19 spread: modelling age and healthcare inequities. medRxiv preprint, doi: 10.1101/2020.05.17.20104976

James A, Plank MJ, Binny RN, Lustig A, Steyn N, Hendy SC, Nesdale A, Verrall A (2020b). Successful contact tracing systems for COVID-19 rely on effective quarantine and isolation. medRxiv preprint, doi: $\underline{10.1101 / 2020.06 .10 .20125013}$

James A, Plank MJ, Hendy SC, Binny RN, Lustig A, Steyn N (2020c). Model-free estimation of COVID-19 transmission dynamics from a complete outbreak. medRxiv preprint, doi: $\underline{10.1101 / 2020.07 .21 .20159335}$

Jefferies S, French N, Gilkison C, Graham G, Hope V, Marshall J, McElnay C, McNeill A, Muellner P, Paine S, Prasad N, Scott J, Sherwood J, Yang L, Priest P (2020). COVID19 in New Zealand and the impact of the national response: a descriptive epidemiological study. The Lancet Public Health, 5(11):e612 - e623.

Kang SJ \& Jung SI (2020). Age-Related Morbidity and Mortality among Patients with COVID19. Infection \& chemotherapy, 52(2):154-164, doi: 10.3947/ic.2020.52.2.154

Kontis V, Bennett JE, Rashid T, Parks RM, Pearson-Stuttard J, Guillot M, Asaria P, Zhou B, Battaglini M, Corsetti G, McKee M (2020). Magnitude, demographics and dynamics of the effect of the first wave of the COVID-19 pandemic on all-cause mortality in 21 industrialized countries. Nature Medicine, 14:1-0.

Lloyd-Smith JO, Schreiber SJ, Kopp PE, Getz WM (2005). Superspreading and the effect of individual variation on disease emergence. Nature, 438(7066):355-359. 
medRxiv preprint doi: https://doi.org/10.1101/2020.10.20.20216457; this version posted March 22, 2021. The copyright holder for this preprint (which was not certified by peer review) is the author/funder, who has granted medRxiv a license to display the preprint in It is made available under a CC-BY-NC-ND 4.0 International license .

843 Obadia T, Haneef R, Boëlle PY (2012). The R0 package: a toolbox to estimate reproduction

844

845

846

847

848

849

850

851

852

853

854

855

856

857

858

859

860

861

862

863

864

865

866

867

868

869

870

871

872

873

874

875 numbers for epidemic outbreaks. BMC medical informatics and decision making, 12(1), 147.

Parag KV, Cowling BJ, Donnelly CA (2021). Deciphering early-warning signals of the elimination and resurgence potential of SARS-CoV-2 from limited data at multiple scales. medRxiv preprint, doi: $\underline{10.1101 / 2020.11 .23 .20236968}$

Parag KV, Donnelly CA, Jha R, Thompson RN (2020). An exact method for quantifying the reliability of end-of-epidemic declarations in real time. PLoS Computational Biology 16(11):e1008478, doi: 10.1371/journal.pcbi.1008478

Plank MJ, Binny RN, Hendy SC, Lustig A, James A, Steyn N (2020). Effective reproduction number and likelihood of cases outside Auckland. url: https://cpb-apse2.wpmucdn.com/blogs.auckland.ac.nz/dist/d/75/files/2020/09/reff-update-andtravel-model-results-for-release-FINAL.pdf (accessed 9 October 2020)

Statistics New Zealand (2018). 2018 Census of population and dwellings counts. url: https://www.stats.govt.nz/information-releases/2018-census-population-and-dwellingcounts (accessed 4 November 2020)

Steyn N, Binny RN, Hannah K, Hendy SC, James A, Kukutai T, Lustig A, McLeod M, Plank MJ, Ridings K, Sporle A (2020). Estimated inequities in COVID-19 infection fatality rates by ethnicity for Aotearoa New Zealand. medRxiv preprint, doi: $\underline{10.1101 / 2020.04 .20 .20073437}$

Summers JL, Lin H-H, Cheng H-Y, Telfar Barnard L, Kvalsvig A, Wilson N, Baker MG (2020). Potential lessons from the Taiwan and New Zealand health responses to the COVID-19 pandemic. The Lancet Regional Health - Western Pacific. (Accepted, in press).

Verity R et al (2020). Estimates of the severity of coronavirus disease 2019: a model-based 
medRxiv preprint doi: https://doi.org/10.1101/2020.10.20.20216457; this version posted March 22, 2021. The copyright holder for this preprint (which was not certified by peer review) is the author/funder, who has granted medRxiv a license to display the preprint in It is made available under a CC-BY-NC-ND 4.0 International license .

876

877

878

879

880

881

882

883

884

885

886

887

888

889

890

891

892

893

894

895

896

897

898

899

900

901

analysis. The Lancet, 20(6), 669-677, doi: 10.1016/S1473-3099(20)30243-7

Verrall A (2020). Rapid Audit of Contact Tracing for Covid-19 in New Zealand. Ministry of Health, New Zealand.

Verrall A, Norton K, Rooker S, et al. (2010). Hospitalizations for pandemic (H1N1) 2009 among Māori and Pacific Islanders, New Zealand. Emerg Infect Dis., 16:100-2.

Wallinga $\mathbf{J}$ and Lipsitch M (2007). How generation intervals shape the relationship between growth rates and reproductive numbers. Proceedings of the Royal Society B: Biological Sciences, 274:599-604, doi: 10.1098/rspb.2006.3754

Wilson N, Parry M, Verrall AJ, Baker MG, Schwehm M, Eichner M (2020). When Can Elimination of SARS-CoV-2 Infection be Assumed? Simulation Modelling in a Case Study Island Nation. medRxiv preprint, doi: $\underline{10.1101 / 2020.05 .16 .20104240}$

Wilson N, Telfar-Barnard L, Summers J, et al. (2012). Differential mortality by ethnicity in 3 influenza pandemics over a century, New Zealand. Emerg. Infect. Dis., 18:71-77. 